\title{
Leader-Member Exchange in Educational Institutions
}

\author{
Hardianto $^{1}$, Vivi Puspita Sari ${ }^{2}$ \\ DOI: 10.35445/alishlah.v13i2.541
}

Info Artikel

Keywords:

Implementation;

$L M X$;

Educational Institutions

Kata kunci:

Implementasi;

$L M X$;

Institusi Pendidikan

\section{Abstract}

This study is motivated by the lack of reading material related to LeaderMember Exchange (LMX) in educational institutions. LMX studies in Indonesia are more dominant incorporates. The purpose of this study was to determine the study of LMX in educational institutions in Indonesia. This research is library research, the primary source of which is articles from journals. The article was taken from google scholar and eric.go.id search engines with the keywords Leader-Member Exchange. Deductive and inductive methods carried out data analysis. The results showed that LMX influenced OCB, innovative work behavior, job satisfaction, organizational commitment, work engagement, employee voice, and performance. Increasing teacher LMX can be done by increasing self-efficacy and organizational justice.

\section{Abstrak}

Kajian ini dilatarbelakangi oleh minimnya bahan bacaan yang berkaitan dengan Leader Member Exchange (LMX) di lembaga pendidikan. Kajian LMX di Indonesia lebih dominan pada perusahaan. Tujuan penelitian ini untuk mengetahui kajian LMX pada lembaga pendidikan di Indonesia. Penelitian ini merupakan penelitian kepustakaan yang sumber utamanya adalah artikel dari jurnal. Artikel diambil dari mesin pencarian google scholar dan eric.go.id dengan kata kunci pencarian Leader Member Exchange. Analisis data menggunakan metode deduktif dan induktif. Hasil penelitian menunjukkan bahwa LMX mempengaruhi OCB, perilaku kerja inovatif, kepuasan kerja, komitmen organisasi, keterikatan kerja, suara karyawan dan kinerja. Untuk meningkatkan LMX guru dapat dilakukan dengan peningkatan efikasi diri dan keadilan organisasi.

\footnotetext{
${ }^{1}$ Universitas Pasir Pengaraian, Pasir Pengaraian Rokan Hulu, Riau. Indonesia

Email: hardiantocally@gmail.com

2 Universitas Putra Indonesia YPTK Padang, Indonesia

Email: vivipuspitasari@upiyptk.ac.id
} 


\section{INTRODUCTION}

A leader largely determines the progress of an educational institution or school. Leaders play a huge role in determining the direction of the organization they lead. The capacity of its leaders largely determines the progress or decline of an organization. Visionary leaders can bring organizations to face various challenges. Conversely, leaders who do not have a strong vision tend only to carry out routine activities. The leader figure is the carriage of an organization.

In educational institutions or schools in Indonesia, a leader is known as the principal. Meanwhile, for higher education, Indonesia divides it into high schools, polytechnics, institutes, and universities. High school leaders are known as "Kepala Sekolah", polytechnic leaders are known as "Direktur," and the leaders of the institute or university are known as "Rektor". The terms of these positions in education management are known as education managers.

Leadership is an attempt to influence others. An education manager must be able to influence members of his organization to realize the organization's vision. Failure to influence organizational members has an impact on not achieving the organization's vision. Failure to realize the vision means failure in leadership activities. Some leadership styles recognized and applied by leaders include authoritarian style, laissez-faire style, and democratic style. Authoritarian style shows a leader who does not listen to the opinions of his subordinates. The laissez-faire style shows a leader who gives freedom to his subordinates. Meanwhile, the democratic style shows the leader who listens to the opinions of his subordinates. Democratic leadership styles make it easier for subordinates to carry out their duties (Helmi \& Syukron, 2019).

An education manager can also apply the three leadership styles above. Although in practice, it is not found a leader who is rigid with one leadership style. There are found educational managers with an authoritarian style, a laissez-faire style, and a democratic style. The application of leadership styles is believed to affect the performance of educational institution personnel.

Recently, the Leader-Member Exchange (LMX) model is developing. In general, studies of LMX leadership in Indonesia are more widely discussed in corporate organizations. In companies, the results of the LMX research place more emphasis on the influence of transformational leadership on LMX (Haeruddin, 2017); (Rumambi \& Cholil, 2018); (Setiawan et al., 2017) and (Yosier et al., 2019). The results of the above study indicate that transformational leadership affects LMX. Very few researchers have discussed LMX leadership in educational institutions. This paper is expected to provide an overview of the implementation of LMX leadership in educational institutions.

The implementation of leadership activities in companies is fundamentally different from leadership in schools. The leader of a company that aims for profit certainly has a different leadership style than who aims to provide services. The implementation of LMX in companies and schools is also different. Research articles on LMX are dominant for firms. To fill this gap, through this paper, the author describes the LMX in schools.

The author finds that writing about LMX leadership in educational institutions is limited to seeing the effect of several variables on the LMX (Akyel, 2018); (Fahlevi \& Satrya, 2020); (Handayani, 2019) and (Nesia \& Dewi, 2020). This paper describes a collection of variables that affect the LMX and are associated with its implementation in educational institutions. In addition, this paper also describes how to improve LMX in schools. The LMX is still a little discussed in educational institutions in Indonesia.

A leader in his activities certainly needs a subordinate role. The quality of the relationship between leaders and subordinates dramatically affects the quality of organizational work in general. Leaders who have close relationships with subordinates tend to maximize the potential of subordinates to work. Conversely, a leader who has a less harmonious relationship with his subordinates will find it challenging to maximize the potential of his subordinates. The quality of this relationship is an essential part of looking at LMX leadership.

As an education manager, a school principal requires the optimal role of teaching staff (teachers) and education staff. A harmonious relationship between the principal and teachers and 
education personnel will be a massive asset in realizing a developed school. This paper will discuss the study of LMX leadership in educational institutions in Indonesia.

\section{METHOD}

This research uses a library research approach from various sources. According to Rukajat, this library research obtains theoretical data by looking for written and systematic information from several experts who can broaden thinking horizons (Rukajat, 2018). Library research is a series of activities relating to collecting data, reading and taking notes, and processing research materials (Zed, 2008). According to A. Rifqi Amin, library research is carried out only based on written work, including research results, both those that have been and have not been published (Amin, 2012). Library research is a structured inquiry with specific rules and techniques (George, 2008).

In this study, the authors collected data from various articles, books, and other accurate sources to be quoted and analyzed. The author prefers the source of the article. The articles cited are articles taken from google scholar and eric.go.id. The articles studied were articles published in 2017. The number of articles found was 29. This literature study describes the truth from various reference sources then provides assessments and criticisms, conclusions, and suggestions on the events obtained. The content validity test does the validity test. The reliability test was carried out using the intra-rater technique. Deductive and inductive methods carried out data analysis. The article obtained were then reviewed and recorded based on the research findings. After that, they were grouped based on the similarity of research findings. The results of the grouping were analyzed to obtain a conclusion.

\section{FINDING AND DISCUSSION}

\section{LMX Concept in Educational Institutions}

Several experts expressed their opinion about the meaning of LMX. LMX is the quality of the interpersonal exchange relationship between the leader and its members. A high LMX relationship is characterized by friendship, loyalty, respect, professionalism, and contribution. Meanwhile, a low LMX relationship is characterized by a lack of friendship, loyalty, professional respect, and contribution (Setiadi, 2007). Furthermore (Morrow, 2005), LMX is an improvement in the quality of the relationship between supervisors and employees, which will improve the performance of both. Nevertheless, in reality, the relationship between employees and supervisors can be grouped into good and bad relationships. A good relationship will create employee trust, positive attitude, loyalty, but a bad relationship has the opposite effect.

The two opinions above in the world of education, mainly primary and secondary schools in Indonesia, can mean that the LMX of a school principal can be seen from its relationship with school members (teachers and education staff). A high LMX brings loyalty, respect loyalty, a positive attitude, and maximum contribution from the school community. A low LMX certainly brings the opposite situation, such as disrespect, distrust, negative attitudes, and minimal or even noncontributing contributions from school residents.

The quality of LMX in schools is divided into two, namely high LMX quality (in-group) and low LMX quality (out-group). The high quality of LMX can be seen when teachers and education staff in the group carry out their work by the work contract and the agreed main tasks and functions. Teachers and education personnel included in the in-group can also be relied on to carry out tasks, not in the main task or work contract. They want to volunteer for additional work, and they are willing to take responsibility. Subordinates who are close to the leader (in-group) will receive and offer a series of beneficial results, including the attention and support from the leadership, more time provided for work, willingness and awareness to provide ideas, and fewer work problems (Pradhana, 2021).

Low-quality LMX (out-group) involve exchanges limited only to the employment contract and principal tasks and functions. So it can be said that teachers and education personnel included 
in this out-group will only carry out routine tasks according to the work contract. They do not want to be involved in activities other than what has been agreed upon.

In the in-group, teachers and education personnel are more trusted and get greater attention from the headmaster. Teachers and education personnel also have special privileges, such as additional rewards for doing a better job. Teachers and education staff who are members of the outgroup get limited time from the headmaster. The relationship between the headmaster and teachers and education staff in the out-group is based on a formal relationship which can usually be seen from the use of language when communicating. The language used tends to be formal and stiff.

The LMX theory describes how principals and school members (teachers and education staff) develop relationships individually. When the relationship develops, the room for movement given by the headmaster to the school community will increase. It will lead to a positive relationship between the two. A positive attitude is such as respect and mutual trust. Conversely, when the relationship does not develop, both parties have a sense of distrust and negative attitudes. Therefore, the headmaster needs to develop this relationship.

(Liden \& Maslyn, 1998) suggest that the Leader-Member Exchange (LMX) dimension is divided into four categories. The author will explain this category in the context of educational institutions or schools, namely:

1) Affection is the mutual influence of the headmaster and teachers and education staff based on interpersonal attractiveness, not only from the professional values of workers. For example, the headmaster builds a friendly attitude with the teacher. The principal or teacher exchanges greetings and the principal's open attitude towards suggestions from the teacher.

2) Loyalty is an expression to fully support the goals and personal character in the reciprocal relationship between the principal and the teacher. Loyalty involves loyalty to an individual that is generally consistent from situation to situation-for example, teachers who are loyal to the leadership of the headmaster.

3) Contribution is the perception of task-oriented activities at a certain level among each school member to achieve common goals. Teachers who perform well and impress the headmaster will lead to a higher exchange quality than teachers who underperform. Teachers who have good performance get more attention from the headmaster than teachers with mediocre performance.

4) Professional respect is the perception of how each reciprocal relationship can build a reputation inside or outside the school. This perception can be based on historical data about the person either inside or outside the school. Perception can also be built on other professional recognition that a person achieves. So, it is possible that the perception of respect for a person existed before working with or meeting that person. For example, principals who have specific achievements and are often discussed as role models will make building better relationships with teachers and education staff easier.

According to (Sparrowe \& Liden, 1997), there are several stages in the Leader-Member Exchange (LMX) relationship process. It can be exemplified in educational institutions as follows:

1) Testing and Assessment, at this stage, there is still no relationship between the principal and his subordinates (teachers and education staff). The headmaster is still considering which can be included in-group or out-group based on subjective or objective criteria.

2) Development of Trust, at this stage, the principal provides new opportunities and challenges to foster a sense of trust between them. In return, teachers and education staff included in the in-group category will show loyalty to the headmaster.

3) Creation of Emotional Bond, a teacher or education staff who has a good relationship with the principal can enter this stage. The relationship and bond between the two become emotionally intense. At this stage, a teacher and education staff have a high commitment to the headmaster. 


\section{The Importance of LMX in Educational Institution}

A high LMX will have an impact on optimizing the achievement of school goals. Therefore, the role of the headmaster in building a high LMX is very much needed. A high LMX level will impact the ability of teachers and education staff to bring out their best to the maximum. When all components can bring out their best, of course, the achievement of school goals will be easier to achieve. Of course, when the LMX is low, communication between the principal and teachers, and education personnel is hampered. Low LMX levels can prevent someone from bringing out their best (Lucas et al., 2015). When the best abilities cannot be issued, of course, the goals will not be achieved optimally.

Apart from its relation to general school objectives, LMX is important in enhancing several organizational behaviors. First, LMX has a significant and positive influence on Organization Citizenship Behavior (OCB). This opinion is by the results of research by (Hardjo \& Munisa, 2017); (Hendrawati \& Tjahjaningsih, 2019), (Mayasari, 2019). It means, to improve OCB, the school needs to increase the LMX.

If the interaction of the headmaster with teachers and education staff is of high quality, the headmaster will have a favorable view of teachers and education staff. This causes teachers and education staff to feel that the headmaster provides a lot of support and motivation. This increases their self-confidence and respect for the principal. Thus they are motivated to do more than expected by the principal. OCB is a voluntary effort to make various efforts that exceed its primary obligations or duties and functions (Hardianto, 2019).

Second, LMX has a positive and significant influence on innovative work behavior. This opinion is by the research results of (Putri et al., 2020); (Widyastuti \& Kusmaryani, 2020). Therefore, to improve innovative work behavior, it is necessary to increase the LMX. Innovative work behavior is behavior to introduce new ideas useful for organizational progress, from processes, products, and procedures that aim to make a profit (De Jong \& Den Hartog, 2010). A teacher has innovative work behavior if he can carry out fun and varied learning. A high LMX will give teachers and education staff room to innovate. This space for innovation can increase innovative behavior at work.

Third, LMX has a positive and significant effect on job satisfaction. It is in line with the results of research (Handayani, 2019); (Lopez \& Whitaker, 2018); (Nesia \& Dewi, 2020). In increasing job satisfaction, it is necessary to increase the LMX. Job satisfaction is the teacher's pleasure with the work they have done (Hardianto, 2018). The feeling of mutual trust between the principal and the teacher certainly increases the teacher's pleasure in his work. High LMX creates a sense of friendship, mutual trust and mutual respect, making teachers feel happy with their work. This pleasure is what brings satisfaction at work. It is therefore essential to increase the LMX in schools.

Fourth, LMX has a direct and significant effect on organizational commitment, employee voice, and work engagement. The effect of LMX on the three variables was stated in three studies; namely, LMX has a direct and significant effect on organizational commitment (Hidayah, 2020). LMX has a direct and significant effect on employee voice (Gürler \& Simsek, 2018). LMX has a positive and significant relationship to work engagement (Prilestari \& Purba, 2019). It means that to increase organizational commitment, employee voice and work engagement need to increase the LMX. Organizational commitment is an attitude where individuals try to maintain their membership in the organization, meeting organizational expectations to realize organizational goals. A high LMX, such as an attitude of mutual trust, makes teachers and education staff increasingly committed to the school. High commitment indeed results in the progress of the school. Therefore, it is essential to increase the LMX in schools.

Employee voice is the ability of employees to express ideas, feelings, and concerns related to their work (Morrison, 2011). Teachers and education staff who have employee voices dare to express their opinions. When the LMX is high, teachers and education staff find it easier to convey 
aspirations, information, and beliefs about their work situations. When the voice of teachers and education staff are listened to by the principal, it causes them to give their best workability. Therefore, the LMX also needs to be improved, so that employee voice also increases.

Work engagement is a psychological condition related to positive attitudes, thoughts, and feelings related to work with enthusiasm, dedication, and absorption (Schaufeli et al., 2002). Teachers with high work engagement can be seen as always enthusiastic about working and dedicated to advancing education. A high LMX, such as a positive attitude from the principal, certainly causes teachers to work with enthusiasm and dedication.

Fifth, there is a positive and significant effect of LMX on performance. It was obtained from the results of research by Patoni (2020), (Prastiwi et al., 2020), (Suarsa, 2020), and Suryadi (2017). In improving teacher performance, it is necessary to increase the LMX. Performance is the achievement or achievement of a person concerning the tasks assigned to him (Marwansyah, 2016). Teachers who have high performance are teachers who excel at work. A high LMX is characterized by mutual trust and contribution. With an atmosphere of mutual trust, of course, the teachers work optimally. It triggers a satisfactory work result or achievement. Principals are expected to understand their work and foster better relationships with teachers and education personnel (subordinates) (Lamm \& Priest, 2019).

\section{Efforts to Implement LMX}

A good leader is a leader who has excellent ideas and concepts. Not only have ideas, but good leaders can also realize ideas through a significant action or action (Syarif, 2018). To realize ideas, we need a certain way so that all components in the organization work optimally. Likewise, school principals need to create an atmosphere in schools so that school members can work optimally. One way is by implementing LMX.

Based on the research results, it is known that the ways that can be done to make the LMX high include:

1) The application of organizational justice. Organizational fairness is the perception of organizational members regarding the extent to which they are carried out fairly without differentiating one another by the provisions of the organization. Schools with a high level of organizational fairness do not differentiate one teacher from another. Rewards and punishments are given based on performance. Schools that employ organizational justice will increase the LMX. The level of organizational justice has a positive and significant relationship to the LMX (Akyel, 2018).

2) Increased Self-efficacy. Self-efficacy is self-confidence in having the ability to take the desired action. Teachers who have high self-efficacy are always confident in their ability and success in doing something. With self-efficacy, teachers feel able to contribute optimally in school. This led to the emergence of the LMX. There is a positive effect of self-efficacy on the LMX (Fahlevi \& Satrya, 2020).

Teachers and education personnel with high LMX quality received more exciting and challenging assignments and communicated more frequently with school principals. Teachers with high LMX also received more support from the headmaster. Teachers with high LMX are expected to be able to work harder and sacrifice more. Teachers with high LMX are also able to assume more responsibility and spend more time in school.

\section{CONCLUSION}

High LMX will lead the headmaster, teachers, and other education staff to have mutual respect and trust and contribute the maximum in the works. A high LMX will increase OCB, innovative work behavior, job satisfaction, work engagement, employee voice, organizational commitment, and performance. Therefore it is essential to increase the LMX in educational institutions. Increasing the LMX can be done by increasing organizational justice and self-efficacy. 
In essence, a high LMX does not always have a positive impact on schools. Teachers and education personnel who feel close to the school principal may not work optimally because they think their position is safe. It needs to be avoided by always paying attention to a professional attitude at work.

The limitation of this research is that it only looks at the results of previous studies without conducting a field study. This research has implications for educational institutions. This research is useful so that LMX in educational institutions can be improved. Theoretically, this research has implications for strengthening existing theories. Practically, this research has implications for increasing LMX in educational institutions. For LMX to be improved, principals need to increase the school community's sense of organizational justice and self-efficacy. For further researchers, this research has the potential as a reference in discussing LMX in educational institutions.

\section{REFERENCES}

Akyel, Y. (2018). Analysis of relationships between coaches' organizational justice and leadermember exchange by structural equation modeling. International Journal of Higher Education, 7(3). https://doi.org/10.5430/ijhe.v7n3p197

Amin, A. R. (2012). Penelitian Kepustakaan (Library Research). https://www.banjirembun.com/2012/o4/penelitiankepustakaan.html.

De Jong, J., \& Den Hartog, D. (2010). Measuring Innovative Work Behavior. Creativity and Innovation Management, 19(1).

Fahlevi, M., \& Satrya, A. (2020). Efek Mediasi Leader Member Exchange, Motivasi Instrinsik dan Pemberdayaan Psikologis pada Pengaruh Ethical Leadership Terhadap Kreativitas Aparatur Sipil Negara. MIX: Jurnal Ilmiah Manajemen, 10(01), 45-64.

George, W. N. (2008). The Elements of Library Research: What Every Student Needs to Konow. Princeton University.

Gürler, M., \& Simsek, Y. (2018). Analyzing the Impact of Leader-Member Exchange on Employee Voice: The School Principal as a Leader and the Teacher as a Member. Online Submission, 5(8).

Haeruddin, M. I. M. (2017). Komparasi Gaya Kepemimpinan Transformasional dan Gaya Kepemimpinan Transaksional di Dalam Teori Leader-Member Exchange (LMX). Jurnal Economix, 5(1).

Handayani, M. M. (2019). Pengaruh Self Efficacy Dan Emotional Intelligence Pemimpin Perempuan Terhadap Kepuasan Kerja Pegawai Dengan Leader Member Exchange (Lmx) Sebagai Variabel Pemediasi. Jurnal Ekonomi, Bisnis, Dan Akuntansi, 21(2). https://doi.org/10.32424/jeba.v21i2.1326

Hardianto. (2019). Meningkatkan perilaku kewargaan organisasi bagi guru dan tenaga kependidikan. III(1), 45-53.

Hardianto, H. (2018). Optimalisasi Kepuasan Kerja Guru. Kelola: Jurnal Manajemen Pendidikan, 5(2). https://doi.org/10.24246/j.jk.2018.v5.i2.p190-195

Hardjo, S., \& Munisa. (2017). Hubungan Persepsi Iklim Organisasi dan Interaksi Atasan dan Bawahan (Leader Member Exchange) dengan Organizational Citizenship Behavior Pada Pegawai Perguruan Panca Budi Medan. Jurnal Psychomutiara, 1(1), 40-50.

Helmi, J., \& Syukron, D. (2019). The Principal's Leadership Style In Improving Teacher Performance. AL-ISHLAH: Jurnal Pendidikan, 170. https://doi.org/10.35445/alishlah.v11i2.121

Hendrawati, S. R., \& Tjahjaningsih, E. (2019). Efektvitas Leader Member Exchange dan Karakteristik Pekerjaan Terhadap Organizational Citizenship Behavior dengan Moderasi Person Organization Fit (PO-Fit). Jurnal Bisnis Dan Ekonomi, 26(1).

Hidayah, N. R. (2020). Peran Mediasi Komitmen Organisasional Dalam Pengaruh Antara job Stress, Leader Member Exchange, Perceived Organizational support, dan Efektivitas Pengendalian 
Internal Terhadap Kinerja Auditor Internal Pemerintah. Jurnal Ilmu Ekonomi Dan Bisnis Islam, 1(2), 129-154. https://doi.org/10.24239/jiebi.v1i2.15.129-154

Lamm, K., \& Priest, K. (2019). Evaluating the role of leader member exchange in leadership development program satisfaction. Journal of Agricultural Education, 6o(3), 1-13. https://doi.org/10.5032/jae.2019.03001

Liden, R. C., \& Maslyn, J. M. (1998). Multidimensionality of LMX: An empirical Assessment Through Scale Development. Journal of Management, 24(1).

Lopez, C., \& Whitaker, W. (2018). Student Job Satisfaction and Leader-Member Exchange: Relationships with Employers. Academic Leadership Journal in Student Research, 5(1), 2.

Lucas, A. D., Voss, R. A., \& Krumwiede, D. W. (2015). Institutional Communication Dynamics in Instructional Effectiveness: Development of a Student Self-Report Measure of FVP, LMX, and TMX in a Pedagogical Context. Journal of Learning in Higher Education, 11(1), 91-98. https://search.ebscohost.com/login.aspx?direct=true\&db=eric\&AN=EJ1141944\&site=ehostlive

Marwansyah. (2016). Manajemen Sumber Daya Manusia. Alfabeta. Bandung.

Mayasari, I. (2019). Pengaruh Leader Member Exchange (LMX) dan Quality Work of Life (QWL) Terhadap Organizational Citizenship Behavior (OCB) Dosen STAI NU Jakarta. Jurnal Ilmu Pendidikan, $10(2)$.

Morrison, E. W. (2011). Employee Voice Behavior: Integration and Directions for Future Research. The Academy of Management Annals, 5(1).

Morrow, P. C. (2005). The Role of Leader-Member Exchange in High Turnoverwork Environments. Journal of Managerial Psychology, 2o(8).

Nesia, R. P., \& Dewi, I. G. A. M. (2020). Leader Member Exchange, Pemberdayaan Karyawan Dan Kompensasi Finansial Berpengaruh Terhadap Kepuasan Kerja Pt. Central Hero Manunggal. E$\begin{array}{lllll}\text { Jurnal Manajemen Universitas } & \text { Udayana, } & 9(2), & 617 .\end{array}$ https://doi.org/10.24843/ejmunud.2020.v09.io2.p11

Patoni. (2020). Pengaruh Leader Member Exchange dan Keahlian Teknologi Informasi Terhadap Kinerja Guru SMP di Kabupaten Purwakarta. E-Qien Jurnal Ekonomi Dan Bisnis, 7(2).

Pradhana, B. G. V. (2021). The Role of Psychological Capital and Leader Member Exchange on Participatory Budgeting and managerial Performance. Jurnal Media Ekonomi Dan Manajemen, 36(1), 11-26.

Prastiwi, N. L. P. E. Y., Ningsih, L. K., \& Gorda, A. A. N. E. S. (2020). Perceived organizational support dan kinerja pegawai: leader member exchange sebagai mediator. Kinerja, $17(2), 298-$ 304.

Prilestari, C., \& Purba, D. E. (2019). Pengaruh Leader Member Exchange Dan Masa Kerja Pada Work Engagement Pegawai Dinas Xyz. Civil Service, 13(2), 27-37.

Putri, N. M. D., Ma'ruf, A., \& Sutinah, S. (2020). Pengaruh Leader-Member Exchange dan Psychological Empowerment terhadap Innovative Work Behavior: Review Sistematik. Jurnal Ilmu Sosial Dan Humaniora, 9(1), 156. https://doi.org/10.23887/jish-undiksha.v9i1.24741

Rukajat, A. (2018). Pendekatan Kualitatif dan Kuantitaf (Research Approach). DeePublish, Yogyakarta.

Rumambi, N., \& Cholil, M. (2018). Pengaruh Kepemimpinan Transformasional terhadap Komitmen Organisasi pada BPR Kartasura Saribumi PT dengan Leader MemberExchange sebagai Variabel Intervening. Media Riset Manajemen, 1(1).

Schaufeli, W. B., Salanova, M., Gonzales, V., \& Bekker, A. B. (2002). The Measurement of Engagement and Burnout: A Two Sample Confirmatory Factor. Journal of Happiness Studies, 3 .

Setiadi, N. J. (2007). Personal Characteristic and Creative Performance of Indonesian Radio Station Operating Managers: The Impact of Leader-Member Exchange. Binus University, Jakarta. 
Setiawan, E. W., Hadi, L. P., \& Remiasa, M. (2017). Pengaruh Transformational Leadership dan Leader Member Exchange (LMX) Terhadap Kinerja Karyawan di Moi Garden Surabaya. Jurnal Hospitality Dan Manajemen Jasa, 5(1).

Sparrowe, R. T., \& Liden, R. C. (1997). Process and Structure in Leader-Member Exchange. Academy of Management Review.

Suarsa, S. H. (2020). Kecerdasan Emosional dan Leader Member Exchange Sebagai Faktor Pemicu Kinerja Karyawan. E-Qien Jurnal Ekonomi Dan Bisnis, 7(2).

Suryadi, A. (2017). Pengaruh Leader Member Exchange (LMX) Terhadap Kinerja Pegawai (Studi pada Pegawai di Politeknik Ilmu Pelayaran Semarang). Dinamika Bahari, 8(1), 1775-1785. https://doi.org/10.46484/db.v8i1.56

Syarif, H. A. (2018). Komitmen Organisasi Dan Kinerja Pendidik Dalam Dunia Pendidikan. $A l$ Ishlah: Jurnal Pendidikan, 10(1), 79-88.

Widyastuti, \& Kusmaryani, R. E. (2020). Hubungan Leader Member Exchange dengan Perilaku Inovatif Kerja: Studi Pada Karyawan dengan Pemimpin Perempuan. Jurnal Acta Psychologia, 2(1).

Yosier, S., Riadi, S. S., \& Zainurossalamia, S. (2019). Pengaruh Kepemimpinan Transformasional, Leader Member Exchange, Self Efficacy Terhadap Kepuasan Kerja. Jurnal Manajemen, 11(2).

Zed, M. (2008). Metodologi Penelitian Kepustakaan. Yayasan Obor, Jakarta. 